\section{Mini-Mental State Examination norms in a community-dwelling sample of elderly with low schooling in Brazil}

\author{
Normas do Mini-Exame do Estado Mental para \\ uma amostra de idosos com baixa escolaridade \\ residentes na comunidade no Brasil
}

Instituto de Psiquiatria,
Universidade Federal
do Rio de Janeiro,
Rio de Janeiro, Brasil.
2 Secretaria Municipal de
Saúde de Santo Antônio de
Pádua, Santo Antônio de
Pádua, Brasil.
3 Instituto Virtual de Doenças
Neurodegenerativas do
Estado do Rio de Janeiro,
Rio de Janeiro, Brasil.
Correspondence
J. Laks
Centro para Pessoas com
Doença de Alzheimer e
Outras Desordens Mentais
na Velhice, Instituto de
Psiquiatria, Universidade
Federal do Rio de Janeiro.
Av. Wenceslau Brás 71 fundos,
Rio de Janeiro, RJ
$22290-140$, Brasil.
jlaks@centroin.com.br

\section{Abstract}

The objective of this study was to assess MiniMental State Examination norms of a functionally normal sample of community-dwelling elderly. Illiterate and low-educated subjects who scored less than 5 on the Pfeffer Functional Activities Questionnaire (PFAQ) [ $n=397$; female = 269; mean age $=72.15(S D=7.24)$ years $]$ had the 5 th, 25th, 50th, and 75th percentiles calculated according to age (65-74; 75-84 years). Overall MMSE score was 21.97 (SD = 4.48). Mean MMSE for illiterate younger individuals was 19.46 (SD = 3.47), and the quartile distribution was 14, 17, 19, and 21. MMSE of subjects with 1-8 years of schooling was 23.90 (3.87), and the distribution was 15, 22, 24, and 27. MMSE of older illiterate subjects was $18.11(S D=3.63)$, and the distribution of scores was 13, 16, 18, and 20, whereas subjects with 1-8 years of schooling scored 23.81 $(S D=4.01)$ and the distribution was 15, 22, 24, and 27. These MMSE normative data may help improve the detection of cognitive impairment in Brazil, mainly in the primary clinical setting.

Aged; Educational Status; Cognition
Jerson Laks 1

Elienai Maria Rubim Baptista 2

Ana Lúcia Barros Contino 2

Estevão Oliveira de Paula 1,3

Eliasz Engelhardt 1

\section{Introduction}

The Mini-Mental State Examination (MMSE) 1 is widely used as a screening test for dementia and other cognitive disorders 2,3. However, the role of education in MMSE performance, considered controversial by some authors, may make it difficult to assess some specific populations 4,5,6. According to some studies, MMSE specificity and sensibility are limited when the test is applied to subjects with little or no formal education, thus limiting its appropriateness as a screening instrument for dementia in populations with high illiteracy rates $2,4,5,6$. Inversely, the MMSE is a good instrument when applied to adults (18-60 years of age) who are well-educated (defined as having more than nine years of formal schooling). MMSE sensitivity and specificity rates for detecting dementia in well-educated adults are $100 \%$ and $92 \%$, respectively, whereas in subjects over 60 years of age with less than 8 years of schooling, sensitivity is $63.3 \%$ and specificity $65.2 \% 5$

A common strategy to minimize the effects of educational level is to adjust the MMSE cutoff scores according to schooling. This procedure reduces the number of false-negatives in samples with more schooling and the number of false-positives in the less educated, especially the illiterate 4,2,5. Following the same procedure, several studies have attempted to present MMSE cutoffs adjusted to education in the Brazilian el- 
derly population 7,8 , as well as in other developing countries $4,5,9,10$.

Percentiles provide a less complicated way for clinicians to evaluate the results of an individual MMSE score, taking individual age and schooling into account. The procedure can provide valuable data for comparing an individual's score to that expected in the general population, given the individual's specific demographic characteristics 11,12.

Thus, this study aimed to assess the distribution of MMSE scores into quartiles in a healthy Brazilian community-dwelling elderly sample stratified by age and education.

\section{Method}

Community-dwelling elderly over 60 years of age $(\mathrm{n}=870 ; \mathrm{m}=297, \mathrm{f}=573)$ were screened with the MMSE 1 and the Pfeffer Functional Activities Questionnaire (PFAQ) 13 in a project to evaluate the prevalence of dementia in Santo Antonio de Padua, Brazil. The entire sample has been described in a previous publication 14 . Only "young elderly" individuals, i.e., subjects 65 to 84 years of age, were included in the present study. The original database had included 121 subjects 60 to 64 years of age and 51 individuals over 85 . Of the remaining 698 subjects, data for the PFAQ were missing from 108. Those with scores below 5 in the PFAQ were retrieved from the database. Knowing that functional and cognitive impairment are closely related and that combined use of functional and cognitive scales can improve the detection of dementia in the community, the present sample was considered cognitively normal because of their independent performance in activities of daily living (ADL) 14,15,16,17.

The PFAQ is one of the instruments used to assess ADL in community-dwelling elderly, providing operational descriptions of various functional levels. It has been used in previous Brazilian studies to assess cognitive and functional impairment 14,18,19 and was recently recommended by the Brazilian Academy of Neurology as a tool to screen ADL in community samples 20 . Performance in all activities is assessed by 10 questions with the score ranging from 0 to 3 , according to increasing severity. The maximum possible score is 30 . Functional capacity level varies from 1 (normal) to 7 (severely incapacitated). Subjects scoring higher than 5 are defined as having functional impairment.

The MMSE is a brief, broad-based screening test for cognitive capabilities 2 . It evaluates orientation, attention, concentration, memory, cal- culation, language, and praxis. The score ranges from 0 to 30 .

\section{Statistics}

The descriptive analysis of the sample is presented as means and standard deviations (SD). The sample was stratified into quartiles of MMSE scores $(5 \%, 25 \%, 50 \%$, and $75 \%)$ according to age (10-year intervals) and education (illiterate and 1-8 years of schooling). When results in a given quartile showed decimal values they were rounded to the next lowest integer 2 .

The study was approved by the Research Ethics Committee of the Institute of Psychiatry, Federal University in Rio de Janeiro. All subjects signed the informed consent.

\section{Results}

Of the group who had performed the PFAQ ( $\mathrm{n}=$ 590), the mean age of the sample with scores below 5 on the PFAQ $(\mathrm{n}=397 ; \mathrm{m}=128, \mathrm{f}=269)$ was $72.15(\mathrm{SD}=7.24)$ years.

Overall mean MMSE score was 21.97 (SD = 4.48). For younger individuals, mean MMSE was 19.46 ( $\mathrm{SD}=3.47$ ) for illiterate subjects and 23.90 $(\mathrm{SD}=3.87)$ for those with 1-8 years of schooling. Older subjects with less schooling scored a mean MMSE of 18.11 ( $\mathrm{SD}=3.63$ ), as compared to 23.81 $(\mathrm{SD}=4.01)$ for those with more schooling.

Table 1 shows the MMSE quartile scores according to age and education.

\section{Discussion}

This study shows the distribution of MMSE scores according to age and education (quartiles) in a sample of Brazilian community-living elderly. Although some studies 14,21 have examined this scale's cutoff scores for cognitive impairment in illiterate and less educated elderly in Brazil, there is still a need to establish norms within the Brazilian educational and cultural context. This approach (quartile distribution) has not been tested previously in Brazil, and distribution of scores may help plot individuals within the ranges and aid clinicians with decision-making on diagnostic and intervention issues.

To our knowledge, there is only one published study on the MMSE in community-dwelling subjects in Brazil 21. Our results show the same median MMSE scores for illiterate elderly and those with 1-8 years of schooling (Table 1) when compared to the median for illiterates $(\mathrm{MMSE}=20)$ 
Mini-Mental State Examination (MMSE) scores according to age and education.

\begin{tabular}{|c|c|c|c|c|}
\hline \multirow[t]{3}{*}{ Schooling } & \multicolumn{4}{|c|}{ Age in years } \\
\hline & \multicolumn{2}{|c|}{$65-74$} & \multicolumn{2}{|c|}{$75-84$} \\
\hline & $\begin{array}{c}\text { Illiterate } \\
\text { (n= 93: } m=15 ; \\
f=78)\end{array}$ & $\begin{array}{c}1-8 \text { years } \\
(n=180: m=68 ; \\
f=112)\end{array}$ & $\begin{array}{c}\text { Illiterate } \\
\text { (n= 60: } m=22 ; \\
f=38)\end{array}$ & $\begin{array}{c}1-8 \text { years } \\
(n=64: m=23 ; \\
f=41)\end{array}$ \\
\hline \multicolumn{5}{|c|}{ MMSE quartiles } \\
\hline 5 th & 14 & 15 & 13 & 15 \\
\hline 25th & 17 & 22 & 16 & 22 \\
\hline 50th & 19 & 24 & 18 & 24 \\
\hline 75th & 21 & 27 & 20 & 27 \\
\hline
\end{tabular}

$\mathrm{n}=$ sample size $; \mathrm{m}=$ male; $\mathrm{f}=$ female

and those with 1-4 years (MMSE $=25)$ and 5-8 years of schooling (MMSE $=27$ ) in Brucki's study. The slight difference in the results of the two studies may be explained by the categorization of educational levels into two groups in our study, while the other study 21 stratified its sample into three levels.

Some specific ways of applying the test may account for the discrepant scores among the various studies. For instance, Crum 11 scored either the serial seven or the backward spelling task, whichever scored better, while Huppert 12 omitted the backward spelling task.

MMSE scores in developed countries with large samples of community-dwelling elderly are higher than those in our study 11,12,22, but such studies did not screen subjects with lower education. Colombia may share some characteristics with Brazil, although it has a different language and cultural setting. In Colombia, Rosseli et al. 5 found mean MMSE results according to age and education that could be closer to our results. However, no previous study in Latin America has provided data on the normal distribution of scores into quartiles.

Some limitations of our study must be noted. We defined a PFAQ score of less than five as normal, since functional impairment is highly correlated with cognitive problems 14,15,16,17. Still, some of these individuals may suffer from clinical (and even chronic) diseases that might impair normal cognitive function. However, a normal ADL score can be regarded as a reliable method for ascertaining cognitive stability in a representative sample of elderly in the community 11,23. A review of the instruments used to screen ADL in the elderly did not identify any studies with the PFAQ in Brazil up to 2000 23. Another limitation to the use of the PFAQ in this study is that it has not been validated or culturally adapted in Brazil. However, the only completed community survey on dementia in Brazilian elderly used this instrument as a screening tool 18. Even though the Brazilian Academy of Neurology recommends PFAQ as a screening tool for functional impairment 20, this instrument still needs to be adapted to the Brazilian context.

We also lacked more precise data on years of education in our sample, because most subjects could not report their exact number of years of schooling. We thus considered only two groups (illiterate versus 1-8 years schooling). Many subjects with less education (1 to 4 years of schooling) may actually perform as functional illiterates. This might be a source of lower scores on the MMSE in this sub-sample. However, even if we consider this a problem, the data presented can still be regarded as conservative.

Quartile distribution of MMSE scores in a cognitively normal sample of Brazilian communitydwelling elderly may be more effective to guide clinicians' assessment of individual cognitive results. Special attention should focus on illiterate and low education norms, and the study of score distribution in samples according to age using 5 -year intervals could add further valuable information. These MMSE normative data could help improve the detection of cognitive impairment in Brazil, mainly in the primary clinical setting where elderly with low schooling are screened in relation to various medical complaints. 


\section{Resumo}

Avaliar normas do Mini-Exame do Estado Mental (MEEM) de acordo com a idade e escolaridade de idosos vivendo na comunidade. Calcularam-se os quartis do MEEM para idosos com 65 a 74 e 75 a 84 anos, analfabetos e com 1-8 anos de escolaridade, com pontuação menor que cinco no Questionário de Atividades Funcional de Pfeffer $(Q A F)[n=397$; feminino = 269; idade $=72,15$ (DP = 7,24) anos]. O MEEM total foi 21,97 $(D P=4,48)$. Nos indivíduos mais jovens, o MEEM entre analfabetos foi $19(3,47)$ com quartis de 14, 17, 19, 21. O MEEM dos com 1-8 anos de escolaridade foi 23,90 $(D P=3,87)$, e a distribuição foi 15, 22, 24, 27. O MEEM dos analfabetos mais idosos foi $18,11(D P=3,63) \mathrm{com}$ quartis de 13,16,18,20, enquanto a pontuação dos sujeitos com 1-8 anos foi 23,81 ( $D P=4,01)$, quartis de $15,22,24,27$. Os dados de normatização do MEEM podem ajudar o reconhecimento de distúrbios cognitivos no Brasil, principalmente no atendimento primário.

Idoso; Escolaridade; Cognição

\section{Contributors}

J. Laks proposed the original idea for the article, and was the main author of the manuscript. E. M. R. Baptista and A. L. B. Contino collected data and reviewed the text. E. O. Paula wrote the tables and organized the references. E. Engelhardt wrote part of the article and reviewed the manuscript

\section{Acknowledgements}

The authors wish to thank Luzinete N. O. Alvarenga for her editorial assistance.

\section{References}

1. Folstein MF, Folstein SE, McHugh PR. "Mini-Mental State": a practical method for grading the cognitive state of patients for the clinician. J Psychiatr Res 1975; 12:189-98.

2. Mungas D, Reed BR, Kramer JH. Psychometrically matched measures of global cognition, memory, and executive function for assessment of cognitive decline in older persons. Neuropsychology 2003; 17:380-92.

3. Vega U, Silberman C, Laks J, Braga RJ, Burdick KE. Association of education and cognitive status in Brazilian elderly institutionalized patients with schizophrenia. Schizophr Res 2005; 78:107-9.

4. Ramirez EL, Pallas AJM, Domenech VJ, Pueyo AT, Pena CC, Bargallo EV. Investigadores del proyecto Cuida'l. Detection of cognitive impairment in the population of persons older than 64 years: first phase of the Cuida'l Project. Aten Primaria 2003; 32:6-14.

5. Rosselli D, Ardila A, Pradilla G, Morillo L, Bautista L, Rey O, et al. El examen mental abreviado (MiniMental State Examination) como prueba de selección para el diagnóstico de demencia: estudio poblacional colombiano. Rev Neurol 2000; 30:428-32.

6. Prince M. Dementia in developing countries. Int Psychogeriatr 2001; 13:389-93.
7. Bertolucci PHF, Brucki SM, Campacci SR, Juliano Y. O mini-exame do estado mental em uma população geral. Arq Neuropsiquiatr 1994; 52:1-7.

8. Almeida O. Mini Exame do Estado mental e o diagnóstico de demência no Brasil. Arq Neuropsiquiatr 1998; 56:605-12.

9. Vas CJ, Pinto C, Panikker D, Noronha S, Deshpande $\mathrm{N}$, Kulkarni L, et al. Prevalence of dementia in an urban Indian population. Int Psychogeriatr 2001; 13:439-50.

10. Lin RT, Lai CL, Tai CT, Liu CK, Yen YY, Howng SL. Prevalence and subtypes of dementia in southern Taiwan: impact of age, sex, education, and urbanization. J Neurol Sci 1998; 160:67-5.

11. Crum RM, Anthony JC, Bassett SS, Folstein MF Population-based norms for the Mini-Mental State Examination by age and educational level. JAMA 1993; 269:2386-91.

12. Huppert FA, Cabelli ST, Matthews FE; MRC Cognitive Function and Ageing Study. Brief cognitive assessment in a UK population sample - distributional properties and the relationship between the Mini-Mental State Examination and an extended mental state examination. BMC Geriatr 2005; 5:7.

13. Pfeffer RJ, Kurosaki T, Harrah CH. Measurement of functional activities in older adults in the community. J Gerontol 1982; 37:323-9. 
14. Laks J, Batista EMR, Guilherme ERL, Contino ALB, Faria MEV, Rodrigues CS, et al. Prevalence of cognitive and functional impairment in community-dwelling elderly: importance of evaluating activities of daily living. Arq Neuropsiquiatr 2005; 63:207-12.

15. Bustamante SEZ, Bottino CMC, Lopes MA, Azevedo D, Hototian SR, Litvoc J, et al. Instrumentos combinados na avaliação de demência em idosos. Arq Neuropsiquiatr 2003; 61:601-6.

16. Pfeffer RI, Kurosaki TT, Harrah CH, Chance JM, Bates D, Detels R, et al. A survey diagnostic tool for senile dementia. Am J Epidemiol 1981; 114:515-27.

17. Pfeffer RI, Kurosaki TT, Chance JM, Filos S, Bates D. Use of the mental function index in older adults: reliability, validity, and measurement of change over time. Am J Epidemiol 1984; 120:922-35.

18. Herrera E, Caramelli P, Silveira ASB, Nitirni R. Epidemiologic survey of dementia in a communitydwelling Brazilian population. Alzheimer Dis Assoc Disord 2002; 16:103-8.

19. Nitrini R, Caramelli P, Herrera Jr. E, Bahia VS, Caixeta LF, Radanovic M, et al. Incidence of dementia in a community-dwelling Brazilian population. Alzheimer Dis Assoc Disord 2004; 18:241-6.
20. Nitrini R, Caramelli P, Bottino CMC, Damasceno BP, Brucki SMD, Anghinah R. Diagnóstico de doença de Alzheimer no Brasil. Avaliação cognitiva e funcional. Recomendações do Departamento Científico de Neurologia Cognitiva e do Envelhecimento da Academia Brasileira de Neurologia. Arq Neuropsiquiatr 2005; 63:720-7.

21. Brucki SMD, Nitrini R, Caramelli P, Bertolucci PH, Okamoto IH. Sugestões para o uso do mini-exame do estado mental no Brasil. Arq Neuropsiquiatr 2003; 61:777-81.

22. Bravo G, Hébert R. Age-and education-specific reference values for the Mini-Mental and modified Mini-Mental State Examinations derived from a non-demented elderly population. Int J Geriatr Psychiatry 1997; 12:1008-18.

23. Paixão Jr. CM, Reichenheim ME. Uma revisão sobre instrumentos de avaliação do estado funcional no idoso. Cad Saúde Pública 2005; 21:7-19.

Submitted on $17 /$ Oct/2005

Final version resubmitted on 10/Jan/2006

Approved on 16/Feb/2006 